\title{
To lecture or not to lecture, that is the question! Modern medical and nursing students' perceptions regarding lectures and lecture attendance at the University of Ottawa
}

\author{
El Bialy, S. ${ }^{1}$, Jay, M. ${ }^{2}$, Hebert, Y. ${ }^{3}$, Manhas, N. ${ }^{4}$, Karol, D. ${ }^{5}$
}

${ }^{1}$ Department of Innovation in Medical Education, Division of Clinical and Functional Anatomy, Faculty of Medicine, University of Ottawa ${ }^{2}$ McMaster University

${ }^{3}$ University of Montreal

${ }^{4}$ University of British Columbia

${ }^{5}$ University of Toronto, Canada

Corresponding Author: Safaa El Bialy (selbialy@uottawa.ca)

DOI: doi.org/10.18192/UOJM.v11iS5.4986

Date Submitted: Jan 8, 2021

Date Accepted: Mar 7, 2021

Date Published: Januay 11, 2022

Keywords: Healthcare education, Traditional lectures, Medicine, Nursing, Student attendance Running title: To lecture or not to lecture, that is the question!

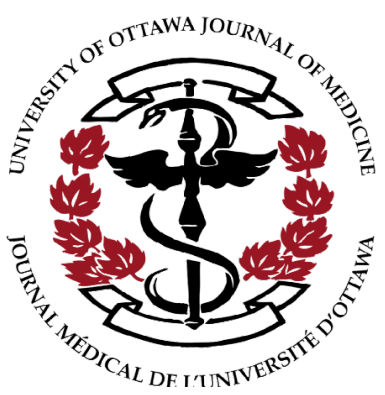

\section{ABSTRACT}

Introduction: Lecture has historically been a core method used for content delivery in healthcare profession education. However, lecture attendance has decreased within the recent generations of students. The current study focus was to assess medical and nursing students' perceptions regarding lecture attendance.

Methods: To assist with this, second year medical and nursing students were requested to answer a 10-item survey. The overall response rate on the survey was $34.4 \%$ ( 110 out of 320 medical students), and $44.2 \%$ (95 out of 215 nursing students).

Results: The results show that even with the tech-oriented newer generations, students still value lectures as a way of acquiring information. Not all students have the same learning style; however, they will mostly attend classes if they find the subject interesting while bearing a high relevance to evaluation, if the lecturer is engaging and offering valuable information, and if they are actively learning.

Conclusions: Although factors driving and hindering lecture attendance vary between medical and nursing students, they both agree that traditional lectures are an effective approach to learning.

\section{RÉSUMÉ}

Introduction: Les cours magistraux ont toujours été une méthode essentielle de transmission du contenu de l'enseignement dans le domaine de la santé. Cependant, l'assiduité aux cours magistraux a diminué au sein des dernières générations d'étudiants. Cette étude a pour but d'évaluer les perceptions des étudiants en médecine et en soins infirmiers concernant la participation aux cours magistraux.

Méthodologie: Ainsi nous avons demandé à des étudiants en deuxième année de médecine et en soins infirmiers de répondre à un questionnaire en 10 points. Le taux de réponse global à cette évaluation a été de 34,4\% (110 étudiants en médecine sur 320) et de 44,2\% (95 étudiants en soins infirmiers sur 215).

Résultats: Les résultats montrent que, malgré l'orientation technologique des nouvelles générations, les étudiants apprécient toujours les cours magistraux comme moyen d'acquérir des informations. Tous les étudiants n'ont pas le même style d'apprentissage ; cependant, ils assisteront le plus souvent aux cours s'ils trouvent le sujet intéressant et très pertinent pour l'évaluation, si le conférencier est engageant et offre des informations précieuses, et s'ils apprennent activement.

Conclusions: Bien que les facteurs qui favorisent ou entravent la participation aux cours magistraux varient entre les étudiants en médecine et les étudiants en soins infirmiers, tous s'accordent à dire que le cours magistral traditionnel est une approche efficace à l'apprentissage. 


\section{INTRODUCTION}

The lecture has a long and venerable place in the history of medical education. ${ }^{1}$ Lectures offer discipline, a good learning environment, and students enjoy attending them. $^{2}$ Researchers have identified that students' desires to attend lectures are fueled by the excitement of intellectual discovery, presentation of challenging and provocative ideas, arguments and counterarguments, desire for knowledge, stimulation of interest, and clarity of explanation and enthusiasm. ${ }^{3}$ Over the past few years, the question of whether the lecture is an effective teaching method has been a topic of heated debate in the field of higher education. ${ }^{2,4,5}$ Recently, the value of the lecture has been increasingly questioned for a number of reasons; waning lecture attendance rates by students, heightened emphases on active learning, interactive modes of teaching and technological advances that allow for the instructional component of lectures to be delivered online. ${ }^{6}$

Researchers both defend and deride lectures as a mode of learning. Donald Clark, for example, describes the face-to-face lecture as 'a lazy and damaging pedagogy'. Harvard physicist Eric Mazur suggests that 'it is almost unethical to be lecturing'. ${ }^{8}$ Further, Kelly et al. observed student engagement in three types of classrooms (lecture, problem based and team based classrooms), and found engagement to be lowest in the lecture theater. ${ }^{9}$ Typically, $^{2}$ less than half of the students attend, even though those who attend score higher on examinations than those who are absent. ${ }^{10}$

Those in favour of retaining face-to-face lectures suggest that when done well, lectures can be informative, engaging, inspiring and even transformational learning experiences. ${ }^{2}$ Gunderman describes a great lecture as a work of art, a kind of dance, in which lecturer and listeners watch, respond to, and draw energy and inspiration from each other. ${ }^{11}$ Gysbers et al. found that students 'revealed an emotional attachment to this mode of teaching' and 'were passionate about retaining lectures. ${ }^{2}$ One of the key reasons that students like attending lectures is the potential motivation to learn resulting from the group dynamic in the lecture setting and the presence of the lecturer. ${ }^{2}$ Moreover, Charlton found that lectures are so effective because they exploit the spontaneous human aptitude for learning from spoken (rather than written) information. Literacy is a recent cultural artefact, and for most of their evolutionary history humans communicated with the spoken word. In contrast with speech, all communication technologies-including reading a book on a computer monitor-are artificial and unnatural. Although the social nature of the lecture might be viewed as a peripheral benefit, learning is easier during formal, quiet, real-time social events. ${ }^{12}$

The fact that lectures survived the era of technology and online learning means that they are a valuable tool for learning. An ideal lecture is informative, provocative, and provides a connection between a skilled teacher and an eager learner. Students can argue, ask questions and better understand challenging concepts, not to mention the importance of socializing and collaborating with their peers. ${ }^{1}$

Millennials, born between 1981 and 2000 represent the majority of the incoming group of medical students and residents. ${ }^{13}$ This is the first generation to grow up surrounded by digital media, and as a result, they are fluent with technology in a way prior generations never were. ${ }^{12}$ For this demographic, staying connected to the internet is essential and expected, and they have become accustomed to receiving and communicating information instantaneously. ${ }^{8}$ Millennials may perceive traditional didactics and formal lectures as unengaging. Residency programs have noticed a trend of decreasing attendance in formal lecture series, and awareness of these attitudes has prompted some training programs to shorten didactic programs, reexamine the quality of the content, and address alternative ways of providing information through new technologies. ${ }^{15,16} \mathrm{~A}$ study by Elam et al. suggest that Millennial students prefer hands-on learning experiences in a noncompetitive environment, where they receive individualized feedback, and get to use technology to manage information. ${ }^{17}$ Other studies have suggested that students indicated a preference for lectures combined with group work and discussions; this was ranked as the most preferred instructional format, regardless of generation. ${ }^{18}$

The "millennials" generation perceive learning as an active experience and something no longer relegated to the passive approaches of the past. ${ }^{19}$ So, is our educational system equipped to meet the needs of the students of the digital age? 
The current study aims at exploring the factors affecting lecture attendance amongst medical and nursing students at the University of Ottawa, their preferred method of learning and their perception of the role of traditional lectures in education.

\section{METHODS}

In order to evaluate student views on attendance, a questionnaire in accordance with the literature by Bhati was employed..$^{20}$ The survey questions were divided into different sections, each of which addressed a concern about students' lecture attendance.

\section{SETTING AND SAMPLE SIZE}

The survey consisted of 10 questions, including 5 point Likert-style questions, multiple-choice questions, and short answer questions. Most questions included the option for students to offer open-ended commentary to expand upon their choices. The survey was optimized, adopted to Google forms and sent via email to second year medical students in Spring $2018(n=320)$ and to second year nursing students in winter $2019(n=215)$. A reminder email was sent 4 weeks after the initial one.

\section{DATA ANALYSIS}

Statistics were extracted from Google Drive analytics with the free Spanning Stats for Google Drive. A chi-square test of independence was performed using excel 2016 to examine the difference between medical and nursing students' groups (significant threshold was set at $p \leq 0.05$ ). Specific comments added by medical and nursing students regarding factors driving or hindering lecture attendance that were not addressed in the survey questions are listed in appendix $\mathbf{A}$ and $\mathbf{B}$ respectively.

\section{ETHICAL APPROVAL}

The protocol \# 20180476-01H (outlining the qualitative survey assessment analyses) was reviewed by the Ottawa Hospital Research Ethics Board and approval was granted in September 2018.

\section{RESULTS}

\section{Characteristics of Survey Respondents}

The overall response rate to the survey was $34.4 \%$ (110 out of 320 medical students), and $44.2 \%$ (95 out of 215 nursing students).

\section{Students' attendance per year of studies}

Lectures'attendance was 48/110 (43.6\%) and 14/95(14.7\%) during the first year of studies ( $p \leq 0.03) ; 9 / 110(8.2 \%)$ and $29 / 95(30.5 \%)(p \leq 0.04)$ during the second year of studies amongst medical and nursing students respectively. The majority of medical students $53 / 110(48.2 \%)$ and nursing students 50/95 (52.6\%) attended lectures equally in both years, with no significant differences between both groups $(p \geq 0.1)$.

The top reasons stated by medical students for attending lectures were: 1-the mandatory nature of the lectures (81.8\%), 2- the ability to socialize with their peers $(68.2 \%)$, and 3-the professor's emphasis on important points (67.3\%). The main reasons for nursing students' lecture attendance were: 1-the professor's emphasis on important points (90\%), 2- gaining insight into more important learning objectives (73\%) and 3- the mandatory nature of the lectures (68.4\%) (table 1).

Table 1: Factors driving lectures' attendance by medical and nursing students at The University of Ottawa.

\begin{tabular}{|c|c|c|c|}
\hline $\begin{array}{c}\text { Factors driving } \\
\text { lectures atten- } \\
\text { dance }\end{array}$ & $\begin{array}{c}\text { Medical } \\
\text { students } \\
\mathrm{n}=110\end{array}$ & $\begin{array}{c}\text { Nursing } \\
\text { students } \\
\mathrm{N}=95\end{array}$ & $\begin{array}{c}\text { Chi-square } \\
\text { test } \\
\mathbf{p} \leq 0.05\end{array}$ \\
\hline They are mandatory & $81.8 \% \mathrm{n}=90$ & $68.4 \% \mathrm{n}=65$ & $\leq 0.01$ \\
\hline $\begin{array}{c}\text { To socialize with } \\
\text { other students }\end{array}$ & $68.2 \% \mathrm{n}=75$ & $29.4 \% \mathrm{n}=28$ & $\leq 0.0001$ \\
\hline $\begin{array}{c}\text { The professor em- } \\
\text { phasizes important } \\
\text { points }\end{array}$ & $67.3 \% \mathrm{n}=74$ & $90 \% \mathrm{n}=85$ & $\leq 0.001$ \\
\hline $\begin{array}{c}\text { The lecture assists } \\
\text { me in covering the } \\
\text { objectives }\end{array}$ & $50 \% \mathrm{n}=55$ & $73 \% \mathrm{n}=69$ & $\leq 0.0001$ \\
\hline $\begin{array}{c}\text { Preference of face } \\
\text { to face interaction }\end{array}$ & $47.3 \% \mathrm{n}=52$ & $43 \% \mathrm{n}=41$ & $\geq 0.07$ \\
\hline $\begin{array}{c}\text { The professor gets } \\
\text { us engaged }\end{array}$ & $40.9 \% \mathrm{n}=45$ & $55.9 \% \mathrm{n}=53$ & $\geq 0.1$ \\
\hline $\begin{array}{c}\text { To collaborate with } \\
\text { other students }\end{array}$ & $36.4 \% \mathrm{n}=40$ & $24.2 \% \mathrm{n}=23$ & $\leq 0.005$ \\
\hline
\end{tabular}

The top factors hindering lecture attendance amongst medical students were: 1 -ineffectiveness of the lecture format $(63.5 \%)$, 2- a preference for learning through alternative formats (e.g. video or audio recordings) (43.3\%), and 3 - the perceived low relevance of some content presented in lectures (37.5\%). For nursing students, the main reasons were: 1 - the ineffective lecture format $(67.7 \%), 2-$ the ability to access to PowerPoint 
presentations (36.6\%), and 3- the perceived low relevance of the material to exams (30\%) (table 2). $65 \%(n=71)$ of medical students and $61 \%(n=58)$ of nursing students agreed that traditional lecture is an effective approach to learning in undergraduate education (figure 1). $56.4 \%$ ( $n=62)$ of medical students stated that traditional lectures is their preferred method of learning compared to $27 \%(n=30)$ preferring flipped classroom, and $30 \%(n=33)$ preferring small group learning, and online learning (31\% $n=34)$. 38\% $(n=36)$ of nursing students stated that traditional lecture is their preferred method of learning compared to $19 \%(n=18)$ preferring flipped classroom, $3.2 \%(n=3)$ preferring small group learning, and $7.4 \%(n=7)$ preferring online learning (figure 2).

Table 2: Factors hindering lectures' attendance by medical and nursing students at University of Ottawa.

\begin{tabular}{|c|c|c|c|}
\hline $\begin{array}{c}\text { Factors hindering } \\
\text { lectures atten- } \\
\text { dance }\end{array}$ & $\begin{array}{c}\text { Medical } \\
\text { students } \\
\mathbf{n}=\mathbf{1 1 0}\end{array}$ & $\begin{array}{c}\text { Nursing } \\
\text { students } \\
\mathbf{N}=95\end{array}$ & $\begin{array}{c}\text { Chi- } \\
\text { square } \\
\text { test } \\
\mathbf{p} \leq 0.05\end{array}$ \\
\hline $\begin{array}{c}\text { The lecture format is } \\
\text { not effective }\end{array}$ & $63.5 \% \mathrm{n}=70$ & $67.7 \% \mathrm{n}=64$ & $\geq 0.37$ \\
\hline $\begin{array}{c}\text { Preference to use vid- } \\
\text { eo or audio tapings }\end{array}$ & $43.3 \% \mathrm{n}=48$ & $18.3 \% \mathrm{n}=17$ & $\leq 0.0001$ \\
\hline $\begin{array}{c}\text { The material is } \\
\text { perceived of low rele- } \\
\text { vance to exam }\end{array}$ & $37.5 \% \mathrm{n}=41$ & $30 \% \mathrm{n}=28$ & $\geq 0.1$ \\
\hline $\begin{array}{c}\text { Lectures are sched- } \\
\text { uled early in the } \\
\text { morning }\end{array}$ & $36.5 \% \mathrm{n}=40$ & $21.5 \% \mathrm{n}=20$ & $\leq 0.01$ \\
\hline $\begin{array}{c}\text { Access to PowerPoint } \\
\text { presentation }\end{array}$ & $36.5 \% \mathrm{n}=40$ & $36.6 \% \mathrm{n}=35$ & $\geq 0.33$ \\
\hline $\begin{array}{c}\text { Extracurricular/person- } \\
\text { al activities }\end{array}$ & $27.9 \% \mathrm{n}=31$ & $14 \% \mathrm{n}=13$ & $\leq 0.05$ \\
\hline $\begin{array}{c}\text { Scheduled electives } \\
\text { The professor is not } \\
\text { efficient }\end{array}$ & $19.2 \% \mathrm{n}=21$ & $1.1 \% \mathrm{n}=1$ & $\leq 0.0001$ \\
\hline Prefer self-study & $4.5 \% \mathrm{n}=5$ & $3.2 \% \mathrm{n}=3$ & $\geq 0.4$ \\
\hline
\end{tabular}

Figure 1. Students' perceptions of traditional lectures as an effective approach to learning.

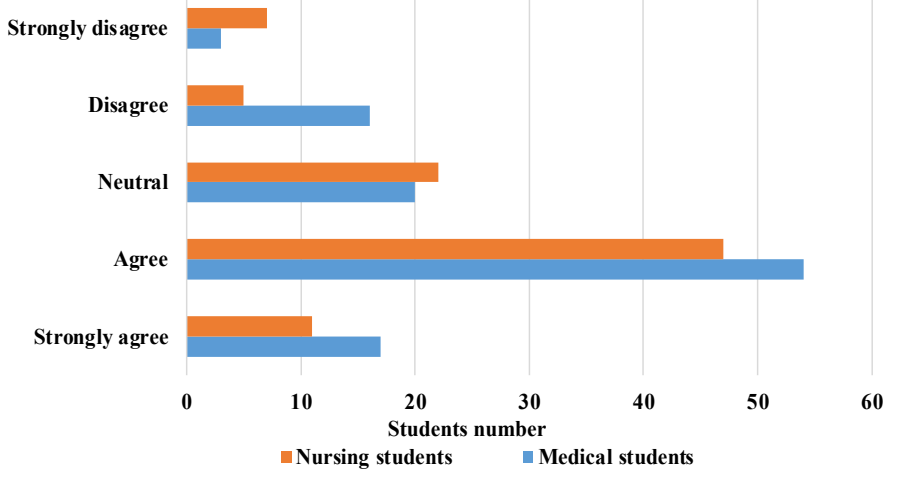

Figure 2: Students' perceptions of the most effective approach to learning.

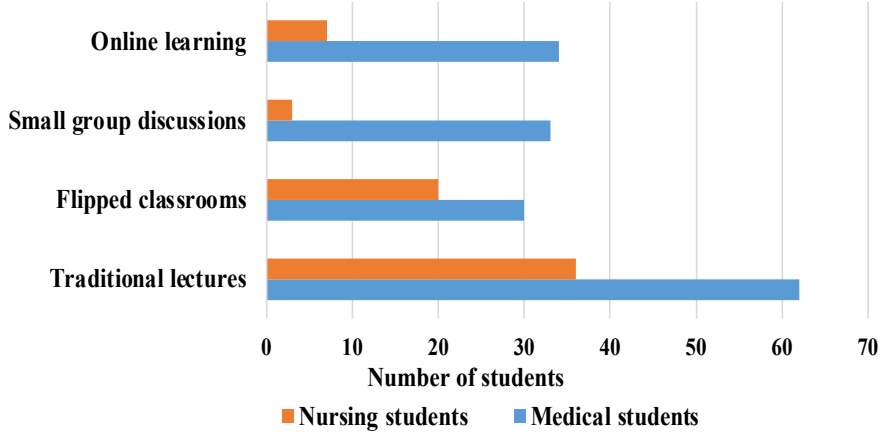

\section{DISCUSSION}

Lectures have long been the "perfect way" of delivering information, where the professors give immediate answers to students' inquiries and where lecturers can use examples and quizzes to enhance critical thinking. ${ }^{21}$ In an attempt to highlight the importance of lectures, Strassman has stated "these days, if you do not follow the instructions that came with your new coffee grinder, you can find a YouTube video that explains how to put it together. So explaining helps and that is what a lecture is, an explanation. Is there anything better than a great talk?". ${ }^{21}$ Such thinking is not new; researchers in the 1970s identified the importance of the lecturer in conveying principles rather than details, ${ }^{22}$ simplifying complex material and communicating with clarity in a structured manner. ${ }^{23}$

However, with the increasing emergence of technology and web-based lecture technologies (WBLTs), there seems to be a decline in lecture attendance amongst university students. ${ }^{2}$ Other reasons for this decline include poor pedagogical skills and material delivery, irrelevant content and lack of motivation. ${ }^{12}$

The current study demonstrates that the top reasons supporting lecture attendance differed amongst medical and nursing students. For medical students, the top two reasons for lecture attendance were that lectures are mandatory $(81.8 \%)$, and they offer an opportunity to socialize with peers $(68.2 \%)$, while nursing students were more focused on gaining insight into the high yield content on exams (90\%) and covering the learning objectives (73\%) (table 1). These differences might be attributed to the fact that many medical students prioritize their learning effort towards excelling at various dimensions of CanMEDS 
roles such as being a communicator, a collaborator an advocate and an expert which allow physicians to utilize an evolving body of knowledge, clinical skills, and professional attitudes to support high-quality and safe patient-centered care. ${ }^{24}$ Both groups of students equally preferred face-to-face interaction with their professors (where teachers can help students in ways that computers cannot), collaboration with peers (where they get to develop teamwork skills) and when the professor initiates engaging activities or discussions (table 1). These results are in accordance with Bhati et al, who found that the main factors affecting student attendance include the mandatory nature of lectures, whether the lecture notes prepared and materials presented are adequate for the learning process, lecturer-lecture-student quality, the scope and difficulty of the subject, and lastly, the possibility of learning about the same subject outside lectures. ${ }^{20}$

Our results are consistent with the results of Sanfilippo, who found that what students find most valuable about lectures is that attendance provides some educational value beyond what they can acquire from their own review of the available information. ${ }^{1}$ Moreover, the social nature of traditional lectures is also valuable. In addition, lower attendance leads to worse learning outcomes. ${ }^{25}$ Earlier, researchers identified the importance of the lecturer in conveying the material in an interesting, clear and logical way. ${ }^{12}$

When it comes to factors hindering lectures' attendance, the current study showed that there was no significant difference between medical and nursing students for some of these factors. Neither would go to classes if the lecture format was ineffective (where the teacher would read from the slides or was not interested in lecturing; if they had access to PowerPoint presentations; and if the material was perceived with low relevance to exam). On the other hand, there were significant differences between medical and nursing students when they had access to video and audio tapings (43.3\% and $18.3 \%$ respectively); when the lectures were scheduled early in the morning $(36.5 \%$ and $21.5 \%$ respectively); when they had extracurricular activities (27.9\% and $14 \%$ respectively), when they preferred to attend scheduled electives (19.2\% and 1.1 respectively) or to collaborate with their peers $(36.4 \%$ and $24.7 \%$ respectively) (table 2 ).

Our results echoed those of Gysbers et al., who found that the early-morning lectures were one common reason that had a significant effect on attendance. ${ }^{2}$ In particular, late nights of study and early morning sleepiness, which can be further compounded by long travel times. The quality of lectures and the inefficiency of the lecturers are some of the main reasons for not attending lectures. Moreover, students do not attend lectures if they feel that their overall examination performance will not be affected. Clark argues that "we are in the tech world now; students have to attend lectures in specific locations and timing which may not be suitable for them". He supports this argument by stating that in a lecture, students are passive observers occupied with note taking, and minor disabilities can massively reduce the benefit from lectures. These factors combined with the cognitive overload that students may face, do not allow the students to learn as effectively. ${ }^{7}$ Many other researchers argue that lecturing is a boring, passive, ineffective and antiquated teaching method that will soon be obsolete. ${ }^{26}$

Millennials interact with technology like no other generation before them and this is affecting how they want to be taught. Their learning and communication style is through multimedia. Also known as the Net Generation, they have been raised in an era of instant access. Their common method of contact is text messaging and instant messaging as well as cell phones. While we hypothesized that lectures would be a less preferred instructional method as learning has moved into web-based tools, ${ }^{27}$ the current study showed that students still perceive the lectures as a discipline they have to follow. A similar finding to that of Zinski et al. who stated that students ranked lecture highly as an instructional method. ${ }^{28}$ These students prefer to attend lectures when the professor is engaging, the subject is interesting and challenging, when they expect to learn and acquire new information and when the lectures relate to what appears on the tests.

Therefore, lectures are not the problem but the context is; some subjects are just more fascinating to learn than others are, and students' preference for learning is not the same. Most of the literature agrees that the top reasons to attend lectures is the efficiency of the professor and the relevance of the material taught to the curriculum. ${ }^{21}$ This means our challenge is not to stop lecturing, but to encourage students to attend lectures for the sake of acquiring the information they need, put emphasis on the importance of lectures in conveying valuable information and clarifying difficult concepts, as well as using a variety of methods to 
deliver information in an engaging and simple way.

\section{CONCLUSION}

Lectures retain a major educational role because they offer a live interaction with professors and make learning easier than with electronic and literacy-based media. Even with the tech-oriented new generations, students still value lectures as a way of acquiring information. Not all students have the same learning style; however, they will mostly attend classes if they find the subject interesting and highly relevant to evaluations, the lecturer is engaging and offers valuable information, and if they are actively learning. In brief, students have to feel that attending classes is worthwhile and adds to their knowledge in an engaging comfortable setting. Although factors driving and hindering lecture attendance vary between medical and nursing students, they both agree that 'traditional learning' is an effective approach to learning.

\section{OTHER CONSIDERATIONS}

Future studies are recommended to:

- Compare lectures' attendance between medical students from different universities.

- Compare lectures' attendance between medical students and students from other faculties (e.g. faculty of arts etc.).

Limitations of the study:

- The sample size is relatively small.

- The study did not correlate the lectures attendance with students' performance on exams.

\section{ACKNOWLEDGEMENTS}

We would like to express our deepest gratitude to Dr. Timothy Wood (DIME professor), University of Ottawa for guiding the statistical methodology of the project.

\section{REFERENCES}

1. Sanfilippo A. Why students do (or do not) attend lectures. Undergraduate school of medicine blog. Kingston (ON): Queen's University. 2016, March 14. Available from: https:// meds.queensu.ca/blog/undergraduate/?p=2792.

2. Gysbers V., Johnston J., Hancock D., Denyer G. Why do Students still Bother Coming to Lectures, When Everything is Available Online? International Journal of Innovation in Science and Mathematics Education. 2011. 19(2):20-36.

3. Feldman K.A. The Superior College Teacher from the Students' View. Research in Higher Education. 1976. 30: 583-645. https://doi.org/10.1007/BF00991967.
4. Alaagib N., Musa OM., and Saeed AM. Comparison of the effectiveness of lectures based on problems and traditional lectures in physiology teaching in Sudan. BMC Medical Education; 2019. 19:365.

5. Deslauriers L, Schelew E, Wieman C. Improved Learning in a Large-Enrollment Physics Class. Science 2011. 332(6031):862-864.

6. French S, \& Kennedy G. Reassessing the Value of University Lectures. Teaching in Higher Education. 2017. (22(6): 639654.

7. Clark D. Ten reasons we should ditch university lectures. Learning and teaching blog. 2014. https://www.theguardian. com/higher-education-network/blog/2014/may/15/tenreasons-we-should-ditch-university-lectures.

8. Schwartz, A. C., McDonald, W. M., Vahabzadeh, A. B., \& Cotes, R. O. (2018). Keeping Up With Changing Times in Education: Fostering Lifelong Learning of Millennial Learners. Focus (American Psychiatric Publishing), 16(1), 74-79.

9. Kelly PA, Haidet $P$, Schneider V, Searle N, Seidel CL, Richards BF. A comparison of in-class learner engagement across lecture, problem-based learning, and team learning using the STROBE classroom observation tool. Teach. Learn. Med. 2005; 17(2):112-118.

10. VanBerkel $\mathrm{H}$, Schmidt HG. On the additional value of lectures in a problem-based curriculum. Educ. Health. 2005; 18(1):45-61.

11. Gunderman R. 'Is the Lecture Dead?' The Atlantic, January 29. 2013. Accessed November 26, 2015. http:// www.theatlantic.com/health/archive/2013/01/is-the-lecturedead/272578/.

12. Charlton BG. Lectures are an effective teaching method because they exploit human evolved 'human nature' to improve learning - Editorial. Medical Hypotheses.2006. 67: $1261-5$.

13. Walsh D: Mind the gap: generational differences in medicine. Northeast Florida Medicine 2011; 62:12-15.

14. Prensky M. Digital natives, digital immigrants. On the Horizon. 2001; 9(5)1-6.

15. Lancaster LC, Stillman D: When Generations Collide: Who They Are, Why They Clash, How to Solve the Generational Puzzle at Work. New York, Harper Collins, 2002.

16. Howell LP, Servis G, Bonham A: Multigenerational challenges in academic medicine: UC Davis's responses. Acad Med. 2005; 80:527-532.

17. Elam CL. Borges NJ. \& Manuel RS: Millennial students perspectives on the medical school learning environment: a pilot study from two institutions. Med Sci Educ 2011; 21:151157.

18. Boateng B. Should generational characteristics be considered in instructional methods? The instructional preferences of Millennials and its implications for medical education. Internet Journal of Medical Education 2010. 2(1):1-6.

19. Kramer M.W. 2017. Forum: The Lecture and Student Learning Sage on the Stage or Bore at the Board? Communication Education. 2017. 66:245-247.

20. Bhati AH., Mandiracioglu A., Orgun F., Govsa F. Why do students miss lectures? A study of lecture attendance amongst students of health sciences. Nurse Education Today. 2013. 33:596-601.

21. Strassmann J.I. iTeach: The importance of lectures. Sociobiology. $2012 . \quad$ https://sociobiology.wordpress. com/2012/01/16/iteach-the-importance-of-lectures/

22. Sheffield EF. Teaching in Universities: No One Way. Montreal: Queen's University Press. 1974.

23. Rennick-Egglestone $S$. This is why traditional lectures are better than watching a video. 2015. retrieved from https:// www.timeshighereducation.com/blog/why-traditionallectures-are-better-watching-video.

24. Royal College of Physicians and Surgeons, Canada. CanMEDS roles. 2015. retrieved from https://www. royalcollege.ca/rcsite/canmeds/about-canmeds-e.

25. Gomis-Porqueras, P., Meinecke, J., \& Rodrigues-Neto, J. New Technologies in Higher Education: Lower Attendance 
and Worse Learning Outcomes? Agenda: A Journal of Policy Analysis and Reform, 2011. 18(1), 69-83.

26. Ben-Naim D. "University Lectures Are a Legacy of our Pre-digital Past." The Sydney Morning Herald. 2012. Accessed December 22, 2015. http://www.smh.com.au/itpro/university-lectures-are-a-legacy-of-our-predigital-past20120710-21t8w.

27. Nicholas A. (2008). Preferred Learning Methods of the Millennial Generation. The International Journal of Learning Annual Review 15(6):1-19.

28. Zinski A. Blackwell TC. F. Belue M., William S. Brooks WS. Is lecture dead? A preliminary study of medical students' evaluation of teaching methods in the preclinical curriculum. International Journal of Medical Education. 2017. 8:326-333. 